\title{
Are the surgeon's movements repeatable? An analysis of the feasibility and expediency of implementing support procedures guiding the surgical tools and increasing motion accuracy during the performance of stereotypical movements by the surgeon
}

\author{
Leszek Robert Podsędkowski ${ }^{1}$, Jacek Moll ${ }^{2}$, Maciej Moll ${ }^{2}$, Łukasz Frącczak ${ }^{1}$ \\ ${ }^{1}$ Politechnika Łódzka \\ ${ }^{2}$ Instytut Centrum Zdrowia Matki Polki
}

Kardiochirurgia i Torakochirurgia Polska 2014; 11 (1): 90-101

\begin{abstract}
The developments in surgical robotics suggest that it will be possible to entrust surgical robots with a wider range of tasks. So far, it has not been possible to automate the surgery procedures related to soft tissue. Thus, the objective of the conducted studies was to confirm the hypothesis that the surgery telemanipulator can be equipped with certain routines supporting the surgeon in leading the surgical tools and increasing motion accuracy during stereotypical movements. As the first step in facilitating the surgery, an algorithm will be developed which will concurrently provide automation and allow the surgeon to maintain full control over the slave robot. The algorithm will assist the surgeon in performing typical movement sequences. This kind of support must, however, be preceded by determining the reference points for accurately defining the position of the stitched tissue. It is in relation to these points that the tool's trajectory will be created, along which the master manipulator will guide the surgeon's hand. The paper presents the first stage, concerning the selection of movements for which the support algorithm will be used. The work also contains an analysis of surgical movement repeatability. The suturing movement was investigated in detail by experimental research in order to determine motion repeatability and verify the position of the stitched tissue. Tool trajectory was determined by a motion capture stereovision system. The study has demonstrated that the suturing movement could be considered as repeatable; however, the trajectories performed by different surgeons exhibit some individual characteristics. Key words: surgical robots, surgeon's movements repeatability.
\end{abstract}

\begin{abstract}
Streszczenie
Rozwój robotów chirurgicznych wskazuje, że będzie można powierzać im coraz większą gamę zadań. W chirurgii miękkiej do tej pory nie było możliwe automatyzowanie procesów chirurgicznych. Dlatego też prowadzone badania miały na celu potwierdzenie tezy, że telemanipulatory chirurgiczne mogą zostać wyposażone w pewne procedury wspomagające chirurga. Pierwszym krokiem w celu ułatwienia pracy chirurga będzie stworzenie takiego algorytmu sterowania, który potrafitby jednocześnie zapewnić automatyzację i utrzymać pełną kontrolę chirurga nad manipulatorem. Algorytm ten będzie polegat na wspomaganiu operatorów telemanipulatorów podczas wykonywania typowych sekwencji ruchów. Takie sekwencje można nazwać stereotypami ruchowymi. Wspomaganie to musi być jednak poprzedzone etapem definiowania punktów referencyjnych określających dokładnie położenie operowanego (szytego) fragmentu. To względem tych punktów zostanie następnie określona trajektoria, po której zadajnik telemanipulatora będzie prowadzit rękę chirurga. Artykut przedstawia pierwszy etap prac polegający na wytypowaniu ruchów, dla których będzie zastosowany algorytm. Została również zamieszczona analiza ruchów chirurgicznych pod kątem ich powtarzalności. Dla ruchu szycia zostały przeprowadzone szczegółowe badania eksperymentalne umożliwiające określenie powtarzalności ruchu oraz weryfikujące sposób określenia położenia tkanki szytej. Trajektoria narzędzia była określana metodą stereowizji. Badania pokazują, że ruch szycia może być uznany za powtarzalny, chociaż trajektoria realizowana przez różnych chirurgów wykazuje pewne cechy indywidualne. Badania dodatkowo wskazały na możliwość wykorzystania opracowywanych procedur do procesu nauczania chirurgów. Słowa kluczowe: roboty chirurgiczne, powtarzalność ruchów chirurga.
\end{abstract}

Address for correspondence: dr inż. Łukasz Frącczek, Politechnika Łódzka, Wydział Mechaniczny, Instytut Obrabiarek i TBM, ul. Stefanowskiego 1/15, 90-924 Łódź, phone: +48 4263123 03, e-mail: lukasz.fracczak@p.lodz.pl 


\section{Introduction}

Cardiac surgery robots were designed for the purpose of assisting the work of surgeons. Their use enables some elements of the conducted operations to be performed with more precision and efficacy. Examples of such robots include Da Vinci, manufactured by Intuitive Surgical [1], Zeus [2], as well as the recently developed Polish robot - Robln Heart. The Robln Heart family of Polish surgical telemanipulators was designed at the Foundation of Cardiac Surgery Development (FCSD). Apart from the employees of FCSD, the science team includes employees of the Lodz, Silesian, and Warsaw Universities of Technology. The following prototypes of the Rob/n Heart robot have been developed since 2003: $\mathrm{RHO}, \mathrm{RH} 1, \mathrm{RH} 2$, and Robln Heart Junior [3, 4]. The year 2007 saw the development of versions $\mathrm{RH} 3$ and $\mathrm{RH}$ Vision [5]. The first surgery performed on an animal subject was conducted in 2009 [6]. During subsequent studies, the FCSD developed the $\mathrm{RH}$ mc2 robot [7], while the Lodz University of Technology developed a sensor for the forces affecting the device [8] and an innovative drive unit [9], among other elements. Further research was aimed at developing various control algorithms.

The use of telemanipulators provides both their constructors and surgeons with the means to advance this field of medical science, combining surgery with technology. At present, the telemanipulator is completely under the surgeon's control. It seems worthwhile to ask if there is any potential for providing additional assistance to the operators in their work. Can the robot suggest certain movement sequences to the surgeon? Are some of the movements repeatable enough to be performed automatically? Are we going to arrive at a point where robots will perform operations planned by the surgeon on their own? Or perhaps they will be able to plan and conduct operations in a completely autonomous manner? Such questions are provocative and will surely raise objections among most experienced surgeons. Nevertheless, adopting a wider perspective reveals that, in many medical centers, some elements of orthopedic operations are already being performed by robots [10] under surgeon supervision.

\section{Aim of the study}

The topic of automation in the context of soft tissue surgery has not yet been approached by scientists. Therefore, the primary objective of this article is to provide an analysis of the surgeon's movements, which will subsequently enable the facilitation of the surgeon's work by the creation of a control algorithm that will concurrently provide automation and enable the surgeon to maintain complete control over the manipulator. The algorithm will support the operators of remote manipulators during the performance of typical movement sequences. Such sequences may be referred to as 'movement stereotypes'. During surgery, they occur, for example, while suturing. Considering the responsibility, experience, and the need for evaluating the current condition of the patient (especially at the surgical site) during such operations, the surgeon cannot be deprived of control over the performed actions - the robot cannot (for now) work in an autonomous fashion.

The crux of the proposed solution is to affect the surgeon's hand with force originating from the drives of the position controller and to guide it along the path defined as the movement stereotype. During a movement performed by the surgeon, the position and velocity of motion along the path would be controlled by the surgeon alone, while motion in other directions (in other degrees of freedom) would be influenced both by the surgeon and the telemanipulator. If the device deviated from the planned path, the motors would generate forces proportional to the deviation, thus making the movement more stable. If the surgeon saw no need for correcting the path, the surgeon would act lightly on the controller, and it would be the controller that would be guiding the surgeon's hand. However, if a need for modifying the path arose (e.g. in order to adapt to local tissue structure), the surgeon would be able to do this by exerting a small but sufficient force. An additional issue which needs to be tackled in order to enable the use of this method is the manner in which the surgeon defines the paths, i.e. movement stereotypes.

A similar principle of influencing the surgeon's hand was employed in the ACrobot device (Active Constraint robot) [11, 12]. In this system for milling the bones for the knee joint socket, the surgeon would define the milling area in the computer system and move on to milling the area with a tool fixed onto the robot but controlled by the surgeon. After crossing the boundary of the area selected for removal, the operating surgeon would sense a force moving their hand back into the area. If the operator deemed it necessary, they could overcome this force and mill deeper, but not exceeding a predefined depth (e.g. $2 \mathrm{~mm}$ ).

During an operation, conducted either directly or with a remote manipulator, the surgeon performs numerous complex manipulative movements. The basic order of these movements is prepared as part of the operation plan. However, the detailed trajectories of all tools are dependent on the situation at the surgical field. The decisions concerning the trajectories of individual movements and incision or suturing sites are undertaken after the start of the surgery based on the appearance, distribution, condition, and physical parameters of particular tissues, among other elements. Furthermore, the precision of individual movements may vary. In order to decide whether the surgeon can be assisted in their performance and in what manner this should be accomplished, an attempt at a classification of surgical movements is presented below. It is followed by a set of principles for determining the location where these movements should be performed, their reference points, as well as the precision with which their trajectory can be defined and with which their repeatability can be assessed. The present analysis will serve the purpose of selecting those movements which require the assessment of repeatability and the development of support methods. 


\section{Analysis of surgical movement repeatability}

The distinction between repeatable and non-repeatable movements was made based on the manner in which the surgeon determines the movement trajectory. If the trajectory is determined based on tissue location before the start of the movement, the movement can be considered repeatable. The following manner of determining repeatability may be assumed for further considerations: if, for a given movement or movement sequence:

- a system of coordinates $X_{c}, Y_{c}, Z_{c}$ related to the operated tissue can be determined,

- the path of the device can be defined as a sequence of consecutive positions and orientations of the device (or, more precisely, the system of coordinates $X_{i}, Y_{i}, Z_{i}$ associated with the tool) measured in relation to the system of coordinates $X_{c}, Y_{c}, Z_{c}$,

- the same movement can be performed multiple times in settings deemed comparable by the surgeon by defining each time the system of coordinates $X_{C}, Y_{c}, Z_{c}$ and calculating the path of the tool,

then the average standard deviation of the tool's pathpoints in a given movement from the path constituting the average of all measured paths will be referred to as path repeatability (the definition is slightly different for industrial robots [13]). This repeatability will be characterized by two parameters - independently for linear position (in millimeters) and angular position (in degrees). As can easily be concluded from this definition, the closer the paths are to each other, the lower the numerical value of repeatability.

Obviously, the value of this path repeatability will be dependent on the type of movement and the experience of the surgeon. A number of other factors can be identified that can also influence this value (the positioning of the tissue in relation to the tool, tissue stiffness, etc.). If repeatability falls below a certain boundary value, arbitrarily set and dependent on the type of performed action, then the movement will be considered repeatable. In turn, if the trajectory of the movement is defined in real time based on changeable needs and visual or force information, or if a system of coordinates $X_{c}, Y_{c}, Z_{c}$ associated with the operated tissue cannot be determined unequivocally, then such movement can be considered non-repeatable.

Below, an attempt at such a classification is presented. It should, however, be stressed that, with the exception of the suturing movement, the classification is based on the subjective experiences of the authors and not on actual measurements. Therefore, further studies can (and should) be conducted in this field of research.

\section{Non-repeatable movements}

A significant portion of the surgeon's motion is dependent on the situation at a particular moment of surgery. Although some movements may appear repeatable, the manner in which they are performed varies to a greater or lesser degree with each operation. This pertains especially to the movements related to pulling the tissue or pushing it away. These movements require constant control, and, de- pending on tissue position at a given moment, need to be modified in a way that enables the tissue to be displaced to the preplanned position. However, as the displacement of one element may influence the position of another, maintaining complete control over the movement and modifying it in real time is indispensable.

Another such movement is the movement of grabbing and displacing the tissue. In this instance as well, the automatic performance of the movement is not possible. Even if we set a point from which a given tissue (item) should be picked up and a point where the given tissue (item) should be left behind, the movement needs to be under constant supervision, so that the position of the manipulator can be modified. This stems from the fact that, when tissue is raised, its base is displaced as well, and the destination point, which theoretically could have been predetermined, becomes displaced in an unpredictable manner. Moreover, the very motion of seizing the tissue must be controlled: tissue elasticity sometimes requires a stronger grip, while, in other cases, its fragility requires a careful grip in order to avoid crushing or severing the tissue.

Another motion which is difficult to program is the motion of cutting with an electrocoagulation device. Although seemingly predictable, moving the device requires constant correction as the tissue being cut undergoes deformation and moves away. Moreover, tissue heterogeneity entails that cutting it is more effective in some areas than in others.

The next analyzed movement is the movement of cutting off a suture. The whole movement leading to cutting off a suture consists in approaching the suture with the scissors and then clamping the scissors. The approach requires precise determination of the location at which the cutting will take place; considering the unpredictable arrangement of the free end of the suture, this requires visual control of the device's position, making the movement non-repeatable.

\section{Repeatable movements \\ Suturing movement}

The suturing movement is repeatable for a given (particular) tissue type. Piercing through the sutured tissue with precision determines good adhesion of the sutured margins after they are brought together. Appropriate depth of the puncture and its distance to the margin of the sutured tissue are necessary for the tissue not to rupture (due to the puncture being too shallow) or ruffle (due to the puncture being too far from the margin). Even distances between successive punctures ensure the best effect possible. Suturing with high precision and at even intervals is of great importance, especially in the case of fragile tissues which can be easily crushed or ruptured. It is also vital to ensure that the points at which both tissues are punctured remain in the same plane perpendicular to the axis of the suture.

The suturing movement consists of three basic stages: 1) placing the tip of the needle on the tissue at the point of puncture, 
2) puncturing through the tissue,

3) piercing the needle out of the tissue.

Then, the needle is moved to the site of the next puncture. In theory, the distance between successive punctures, as well as puncture depth and distance from tissue margin, should be equal (forming a sort of a cube); however, in many instances, surgeons decide to modify this arrangement.

In accordance with the description above, the determination of the system of coordinates $X_{c}, Y_{c}, Z_{c}$ associated with the operated tissue cannot be omitted when determining repeatability. Moreover, the suturing process requires the determination of the type of sutures, as well as additional parameters related to their width and density. This can be done by establishing the following reference points:

1) the first location where the needle is pierced into the tissue,

2) the first location where the needle is pierced out of the tissue,

3) the last location where the needle is pierced into the tissue,

4) the point determining the plane of the sutured tissue.

The remaining parameters of the suturing movement (the distance between the sutures and the depth of the needle puncture) can be set based on the aforementioned "cube principle". Another technique for the performance of repeatable movements is to perform the first "model" movement, set the direction of the incision, input the distance between successive punctures, and order the robot to perform successive sutures.

If the incision is not linear, or if the wound is lacerated, the sites of piercing into and out of the tissue have to be set for each consecutive suture. The robot's task is to then guide the tool along the theoretical puncturing trajectory. In turn, the surgeon's role would be limited to correcting the trajectory to ensure the proper performance of the suturing process.

\section{Incision movement}

Incising tissue is always burdened with the risk of damaging it. Under the pressure of the knife, tissue "gives in" and bends or is displaced. Lack of precise control over the cutting tool may cause tissue damage resulting from an incision that is too deep or too long. The risk of inadvertently moving outside the incision inline and causing tissue damage could be reduced if the movement was stabilized by a robot able to guide the movement of the knife along a predefined trajectory.

In order to perform the movement properly, it is paramount to establish the following reference points:

1) the start of the incision,

2) the end of the incision,

3) the point determining the plane perpendicular to the motion of the knife.

The depth to which the knife enters the tissue (the incision depth) must also be established.

\section{Knot tying movement}

The movement of knot tying is repeatable. In theory, each successive knot is tied in the same fashion. The knot may be tied by placing the suture on the left side over the suture on the right side or the other way around: placing the suture on the left side under the suture on the right side (levo- or dextrorotatory). Moreover, each knot can be a single or a double knot (the so-called surgical knot). Despite the repeatability of these movements, the possibility of their automation appears unlikely. During knot tying, the position of the two suture segments is absolutely unpredictable. The surgeon needs to establish the positions of both sutures, grab them and tie one around the other. This can only be achieved under visual control in order to be able to see the position of the sutures.

Another important factor and an indispensable element of knot tying is the strength with which the knot is tied. It should be tied tightly enough for the tissue margins to be brought together. At the same time, the suture should not cut through the tissue - this happens when the knot is tied too tightly. When pulling on the knot, the surgeon evaluates the relative positions of the tissues brought together, the tension of the suture, and its influence on the surrounding tissues which are flexible and "give in" to the action of the suture. In this fashion, the strength with which the knot should be tied is established and modified depending on the circumstances at the surgical field. Without visual control, it is impossible to properly tie a knot that will bring and hold together the tissue margins.

However, suture position can be established automatically using machine vision. The strength with which the knot is tied can be controlled with the use of force sensors. Thus, the knot tying movement will be classified as repeatable, even though it will not be considered in the currently conducted studies.

\section{Material and methods}

Due to the considerable variety of movements performed by surgeons during operations (even among movements classified as repeatable based on preliminary analysis), the performance of repeatability tests encompassing all these movements exceeds the capacity of both the present article and the research project for which the present study has been conducted. For further analysis of movement repeatability, the clockwise movement of piercing a needle through tissue during suturing (with the so-called forehand technique) performed by a right-handed surgeon employing single loop sutures was selected as an example. We used 3-0 (2 metric) braided polyester sutures and a needle with a curve shaped as a semicircular sector $25 \mathrm{~mm}$ in length with a circular cross section. The study was conducted on animal tissue: a chicken breast was placed in an approximately horizontal position and incised with a straight cut over approximately $35 \mathrm{~mm}$. The measurements were conducted at a work station equipped with a stereo vision measurement system manufactured at the Lodz University of Technology based on own programming. The measure- 


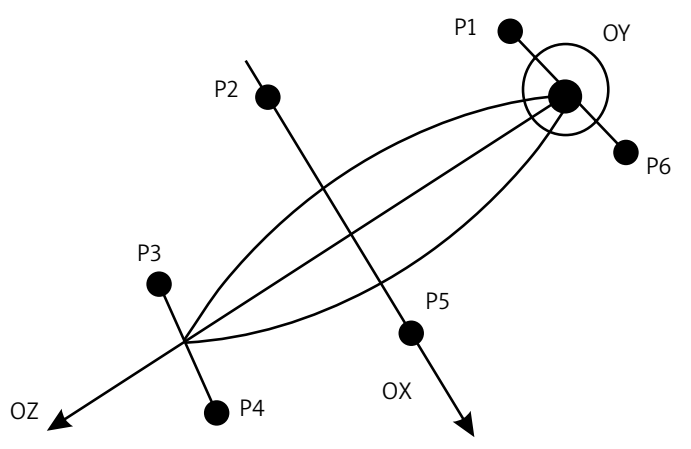

Fig. 1. Points designated by the surgeon and versors constituting the coordinate system designated by the surgeon

ment principle was analogous to measurements performed with the Vector Vision system [14] or other systems used, for example, in neurosurgery. The measurement was based on the images from two cameras (resolution: $1032 \times 776$ ) placed $1 \mathrm{~m}$ from each other and turned so that the angle between them was $60^{\circ}$. Apart from the cameras, the work station included a measurement device, which was mounted on the surgical tool (i.e. a vise with a needle). The precise determination of the tool's spatial positioning was enabled by a set of balls fixed rigidly to the body of the device. The spatial positioning of the balls in relation to the surgical tool was measured by the measurement machine with 0.01 $\mathrm{mm}$ accuracy.

During the conducted tests, film sequences from both cameras were recorded using previously developed software. After the tests were concluded, the same software was used to establish the trajectory of the tool's movement (in accordance with the algorithm presented below). During each repeatability test of the suturing movement, the surgeon would first designate 6 characteristic points associated with the wound incision by placing and holding the needle tip at the characteristic point for 2-3 s (Fig. 1). Based on these points, a matrix was set for transforming the system of coordinates associated with the surgical field into a system of coordinates associated with the cameras. Next, the surgeon performed the suturing movements within the designated area.

Subsequently, based on the recorded film sequences, spatial coordinates of the balls were set for each film frame separately, using the same software. For the ball coordinates of each film frame, a matrix was set for transforming the system of coordinates associated with the surgical field into a system of coordinates associated with the cameras. In this manner, a database of transformation matrices was constructed for each test.

\section{Calculation algorithms}

In order to define tool position at any moment of the surgery, the system of coordinates related to the surgical tool should be transformed into a system of coordinates related to the system designated by the surgeon. The transformations between coordinates recorded in different systems of coordinates were described using a standard $4 \times 4$ matrix:

$$
T_{A}^{B}=\left[\begin{array}{lr}
R_{A}^{B} & r_{A}^{B} \\
0 & 1
\end{array}\right]
$$

In accordance with this notation, matrix $T_{A}^{B}$ is a matrix which transposes point coordinates from coordinate system $B$ to coordinate system $A$, where $\left.R_{A}^{B}\right|_{3 \times 3}$ is a rotation matrix, and $\left.r_{A}^{B}\right|_{3 \times 1}$ is a displacement vector of the center of the coordinate system. The positions of all coordinate systems are presented in Figure 2. The following description substitutes indices $A$ and $B$ with indices $N, I, M, K, C$ in accordance with the labels of the coordinate systems described below.

The following systems of coordinates are marked in Figure 2:

$X_{N}, Y_{N}, Z_{N}-$ a coordinate system related to the needle vise. It is anchored at the point where the needle is gripped and is oriented in the following manner: axis $Z_{N}$ runs along the axis of the tool, axis $Y_{N}$ is normal to the plane including the surface of the tool's jaw, and $X_{N}$ is selected in such a way as to make the coordinate system dextrorotatory.

$X_{1}, Y_{1}, Z_{1}-$ a system of coordinates related to the surgical needle, anchored at the sharp end of the needle and oriented in such a way that the individual axes are parallel to the appropriate axes of the system of coordinates related to the tool.

$X_{M}, Y_{M}, Z_{M}-$ a system of coordinates related to the measurement device which calculated ball positions. It is anchored at the top of the body of the tool's grip. The system is oriented in such a way that the individual axes run along the sides of the body of the tool's grip.

$X_{K}, Y_{K}, Z_{K}$ - a system of coordinates related to the camera system, treated hereinafter as a stationary reference frame.

$X_{P}, Y_{P}, Z_{P}-$ a system of coordinates related to the measurement balls, anchored at the center of mass of the triangle formed by the ball apexes.

$X_{c}, Y_{c}, Z_{c}$ - a system of coordinates related to the surgical field and designated by the surgeon.

Based on the measurements conducted using the measurement machine, the following transforms were formulated: $T_{M}^{1}, T_{M}^{P}, T_{M}^{N}$. On their basis, the following transforms were defined: $T_{P}^{\prime}=\left(T_{M}^{P}\right)^{-1} T_{M}^{\prime}$ and $T_{P}^{N}=\left(T_{M}^{P}\right)^{-1} T_{M}^{N}$.

Stereo visual information enabled the determination of the position of each of the measurement device's balls in the coordinate system of the camera. This, in turn, served as a basis for defining transform $T_{K}^{P}$ from the system related to the measurement balls into the camera system. Based on this transform, the position of the tool $T_{K}^{N}=T_{K}^{P}\left(T_{M}^{P}\right)^{-1} T_{M}^{N}$ and the needle $T_{K}^{\prime}=T_{K}^{P}\left(T_{M}^{P}\right)^{-1} T_{M}^{\prime}$ was defined.

Based on the characteristic points designated by the surgeon (presented in Fig. 1), transform $T_{K}^{C}$ from the coordinate system of the surgeon (of the sutured wound) to the camera coordinate system was defined. Individual points P1-P6 are treated as vectors $r_{K}^{l}$ from the last column of transform $T_{K^{\circ}}^{l}$ 


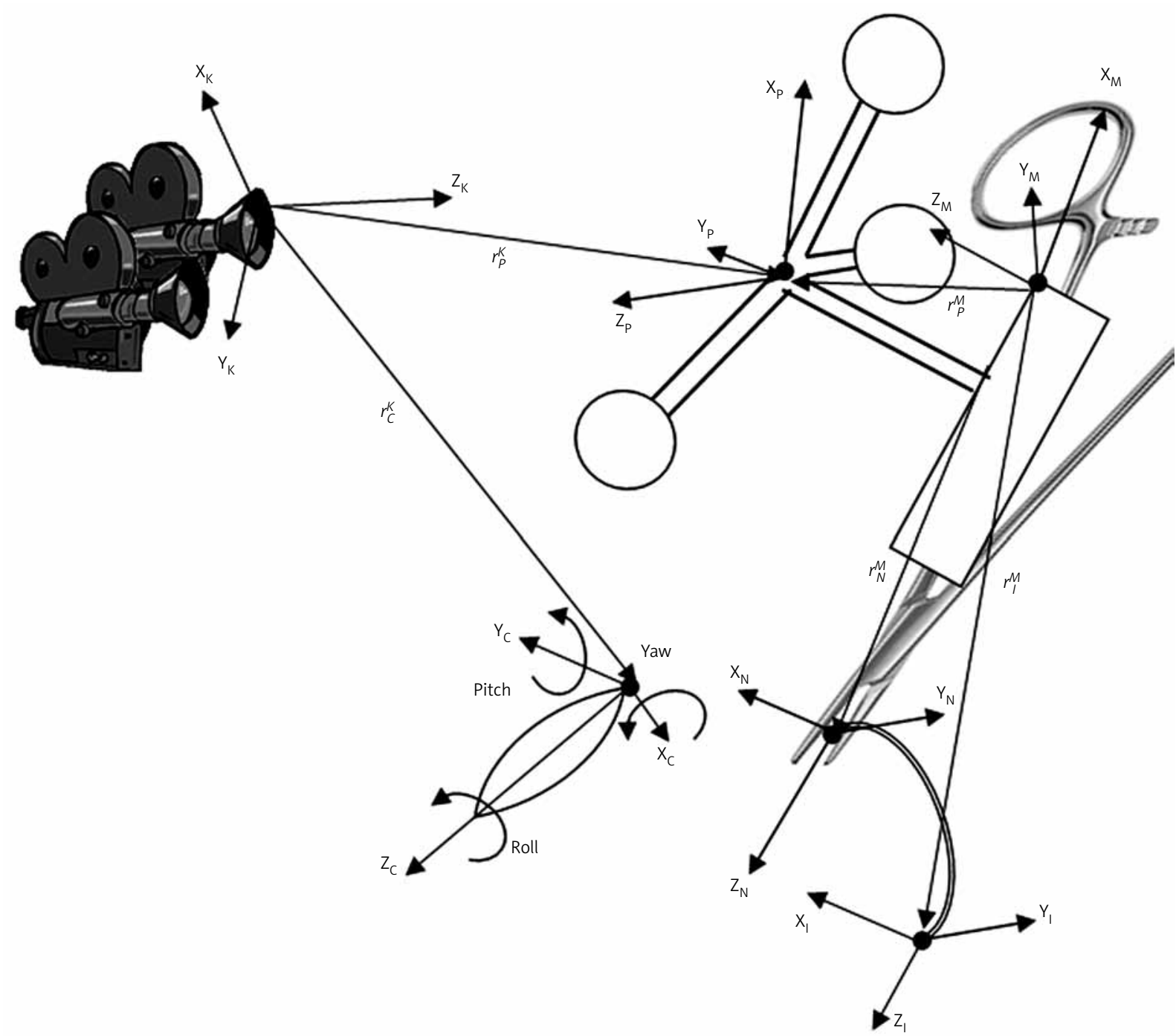

Fig. 2. A description of the systems of coordinates participating in the transformation of the coordinate system associated with the surgical needle into the coordinate system designated by the surgeon

Versor $\mathrm{OZ}$ is constructed based on points $\mathrm{P} 1, \mathrm{P} 3, \mathrm{P} 4$, and $\mathrm{P} 6$ on the basis of the following equations:

$$
\begin{gathered}
P_{A}=\frac{1}{2}\left(P_{1}+P_{3}\right) ; \quad P_{B}=\frac{1}{2}\left(P_{3}+P_{4}\right) \\
\overrightarrow{O Z}=\frac{\overrightarrow{P_{A} P_{B}}}{\left|P_{A} P_{B}\right|}=\left[\begin{array}{l}
O Z_{x} \\
O Z_{y} \\
O Z_{z}
\end{array}\right]
\end{gathered}
$$

Versor OY is defined on the basis of the coordinates of points P2 and P5 using the following relation:

$$
\overrightarrow{O Y}=\overrightarrow{O Z} \times \frac{\overrightarrow{P_{2} P_{5}}}{\left|P_{2} P_{5}\right|}=\left[\begin{array}{l}
O Y_{x} \\
O Y_{y} \\
O Y_{z}
\end{array}\right]
$$

In turn, versor $\mathrm{OX}$ is defined based on the vector product of versors OY and OZ: $\overrightarrow{O X}=\overrightarrow{O Y} \times \overrightarrow{O Z}$. Based on these versors, a rotation matrix is constructed:

$$
R_{C}^{K}=[\overrightarrow{O X} \overrightarrow{O Y} \overrightarrow{O Z}]_{3 \times 3}
$$

The origin of the surgeon's coordinate system $r_{K}^{C}$ is set at point $P_{A}$. Subsequently, a matrix is defined for transforming the system of coordinates related to the needle into the coordinate system related to the system designated by the surgeon:

$$
\begin{gathered}
T_{K}^{P} T_{P}^{\prime}=T_{K}^{C} T_{C}^{\prime} \\
T_{C}^{l}=\left(T_{K}^{C}\right)^{-1} T_{K}^{P} T_{P}^{N}=\left(T_{K}^{C}\right)^{-1} T_{K}^{P}\left(T_{M}^{P}\right)^{-1} T_{M}^{\prime}
\end{gathered}
$$

as well as a matrix for transforming the system of coordinates related to the tool into the coordinate system related to the system designated by the surgeon:

$$
T_{C}^{N}=\left(T_{K}^{C}\right)^{-1} T_{K}^{P}\left(T_{M}^{P}\right)^{-1} T_{M}^{N}
$$

\section{Results}

In order to register stereotypical movements, an experiment was conducted based on the previously described procedure. During the experiment, the surgeon performed the movements of piercing the needle, held by the vise 


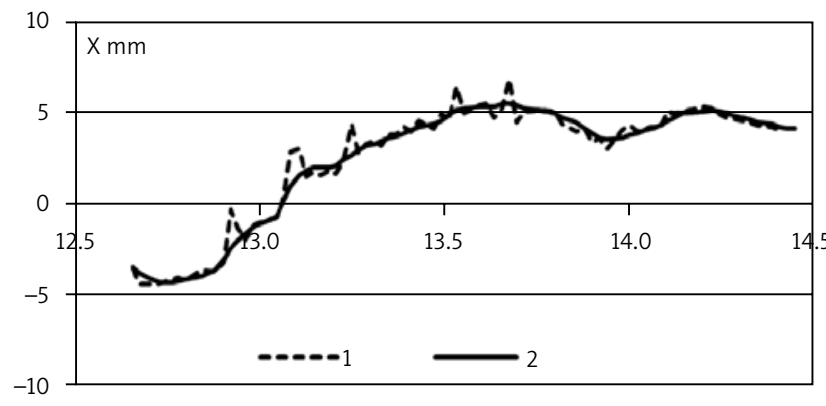

Fig. 3. An example of the process of removing gross measurement errors with a filter

with the measurement device, through the margins of the incised tissue. Consecutive sutures were displaced in axis $Z$ of the system designated by the surgeon (i.e. along the
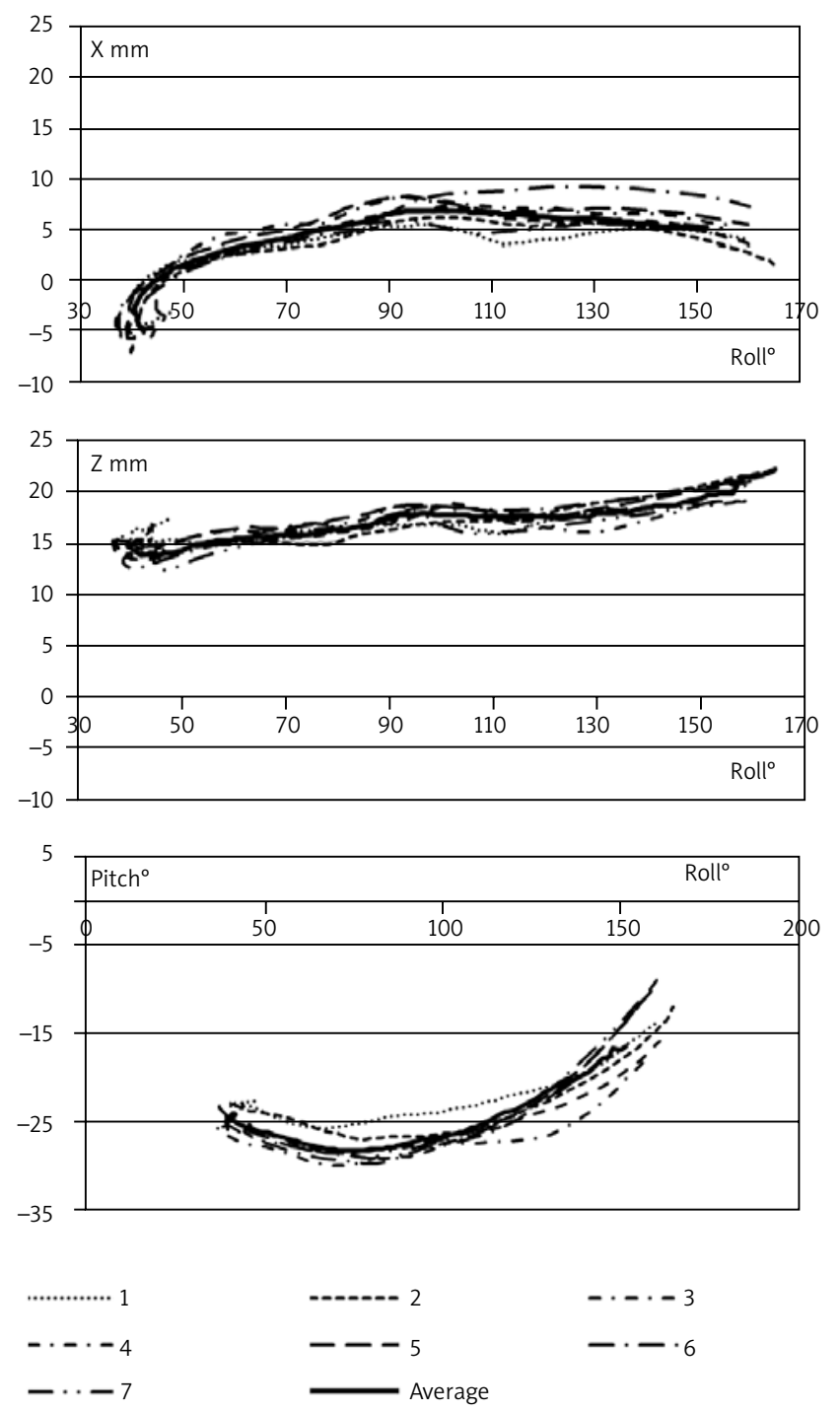

Fig. 4. Exemplary courses of the process of making 7 punctures in incised tissue during the suturing process, presented as changes in the position of the needle tip and its orientation in relation to the sutured tissue in the function of the needle's angle of rotation (roll) and as a path of the needle tip in the $X-Y$ plane wound) by approximately $5 \mathrm{~mm}$. During one experiment, seven sutures were applied. Due to significant disturbances in the measurement of needle position, measurement data underwent filtration with a $2^{\text {nd }}$ order Butterworth filter (filtration parameters: analog cutoff frequency $1 \mathrm{~Hz}$, digital cutoff frequency $4 \mathrm{~Hz}$, measurement sampling frequency $50 \mathrm{~Hz}$ ). Figure 3 shows an example of the suturing trajectory before filtration (1) and after filtration (2) in a time function.

Figure 4 presents examples of suturing courses.

The measurement is presented as the movement of the coordinate system associated with the surgical needle in relation to the coordinate system designated by the surgeon. At this point, a reminder is in order that the coordinate system associated with the needle is anchored at
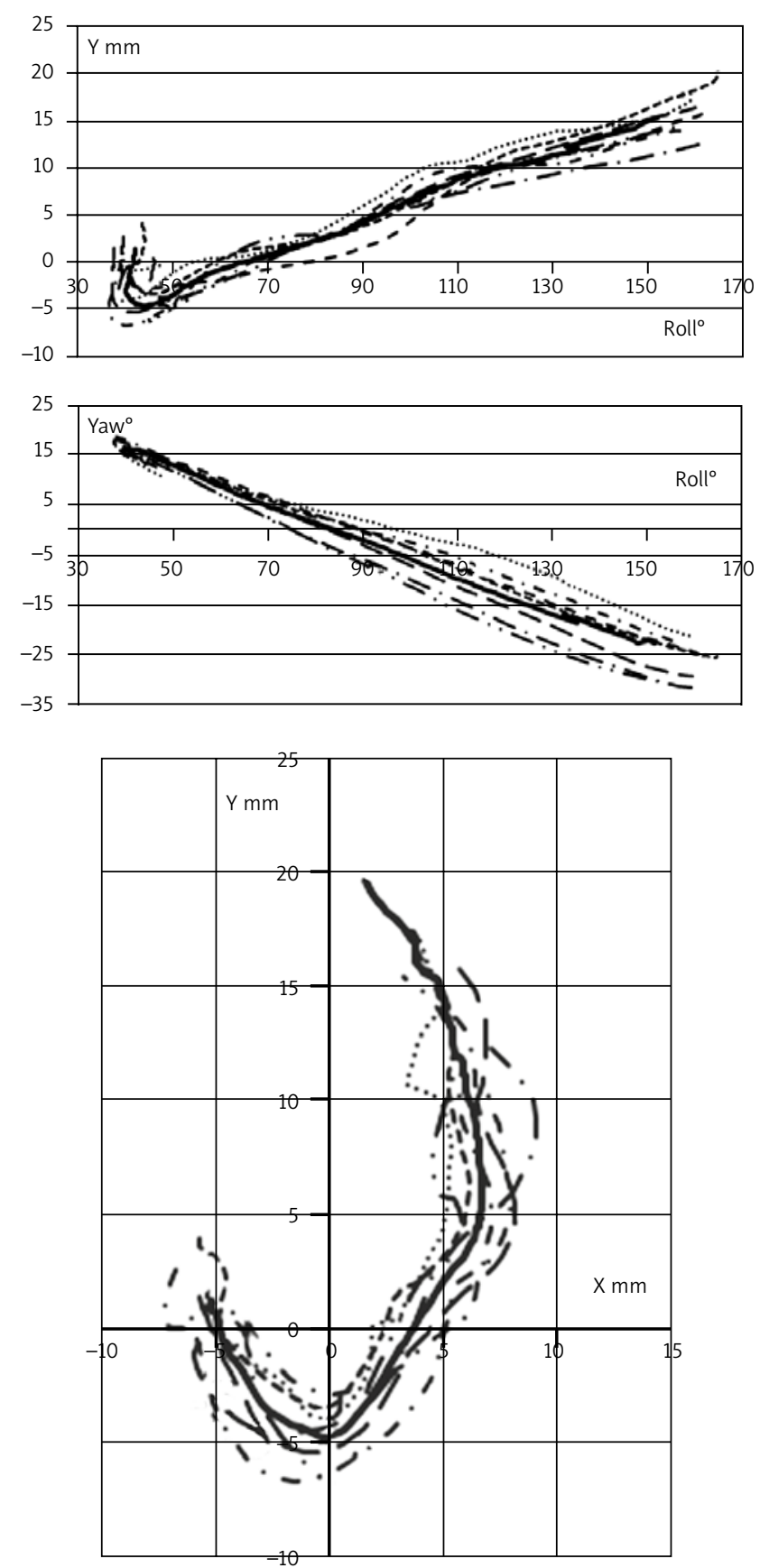
the sharp end of the needle, while the system's OZ axis agrees with the $Z$ axis of the tool. Values $x, y$, and $z$ are the displacement of the origins of these systems, while angles Yaw, Pitch, and Roll are the angles of these systems' rotation in relation to axes $X, Y$, and $Z$ (Fig. 2) (the names of the angles are in accordance with those used in manipulator theory, also known as the "roll-pitch-yaw" representation).

As movement speed varies for each motion, comparing the trajectories (changes in position over time) becomes irrelevant. According to the previously presented definition, the comparison should concern the paths (the geometric locations of consecutive positions and orientations of the tool). This study compared the movements in the function of the angle of rotation around axis Z (the Roll angle), as this coordinate changes linearly with movement. Additionally, a diagram was prepared, presenting the positions of the needle tip in axis $Y$ in the function of positions in axis $X$. The diagram present the trajectory over which the needle tip moves in the plane including the suturing line and perpendicular to the wound/incision line.

As part of the experiment, a statistical analysis of the suturing movement was conducted. In order to conduct the statistical analysis, the individual trajectories of a single motion of piercing into the tissue were first reduced to a common reference frame by moving them in axis $Z$ by $5 \mathrm{~mm}$ (constituting the average distance between sutures) multiplied by an appropriate number. Next, the average tool path was established. It turned out to be one of the more challenging parts of the experiment in terms of methodology. Calculating the average path over time (i.e. the trajectory) was not possible, as the movement speed was different each time. As some experiments recorded needle withdrawals and fragments of variability of the positions of $x, y, z, y a w$, and pitch at a constant roll coordinate, the value of average position as an average of positions at a given roll angle could not have been found. Finding the average position of the sharp end of the needle as an average of points from all paths on the plane perpendicular to the $X Y$ plane and perpendicular to the projection of movement path on the $X Y$ plan was ultimately selected, as it best reflected the ultimate suturing path. The selected average path was designated with continuous lines on the charts of Figure 4. Next, the standard deviation of each suturing path from the average path was established (Table I) along with the average standard deviation of all seven suturing paths constituting a given experiment. Table I presents the values established with this method independently for each movement coordinate of an exemplary experiment.

Table I indicates that the paths of needle movement for experiments no. 4 and 6 exhibit the strongest deviation from the path averaged from all suturing courses. Tool positions in axis $Z$ exhibit the greatest repeatability. In turn, the greatest divergence in angular positions can be observed for the Roll axis.

During the described experiment, a decision was made to verify an additional hypothesis, namely that needle rotation during the motion of piercing the needle out of the tissue occurs around the axis agreeing with the axis of the needle's curve (the axis of the torus of which the needle is a fragment). The movement path of the intersection point of the needle curve axis and the needle plane (hereinafter referred to as the center of the needle's curve) was determined for this purpose. The movement path of the central point of contact between the needle and the vise (the needle grip point) was also determined. The established paths are presented in Figure 5 as the course of variability in coordinates $X$ and $Y$ of appropriate points measured in the system designated by the surgeon in the roll angle function.

The paths demonstrate that, during the suturing process, the needle grip point changes position within the range from -4 to $6 \mathrm{~mm}$ in axis $X$, and from 17 to $30 \mathrm{~mm}$ in axis $Y$. In turn, the displacement of the point associated with the center of the needle curve changes within the range from 1 to 14 in axis $X$ and from 10 to 36 in axis $Y$. A more precise analysis shows that the described courses form a complex movement and not just a rotational movement around a predetermined axis. Therefore, it is impossible to determine one axis of rotation, as its position changes to a certain extent. It can, however, be established that, for the average course in its central range (for the

Tab. I. Statistical data of a single suturing procedure using seven sutures

\begin{tabular}{|c|c|c|c|c|c|c|c|c|}
\hline \multirow{3}{*}{$\begin{array}{l}\text { Process } \\
\text { number }\end{array}$} & \multirow{2}{*}{$x$} & \multirow{2}{*}{$\mathrm{y}$} & \multirow{2}{*}{ z } & \multirow{2}{*}{ Yaw } & \multirow{2}{*}{ Pitch } & \multirow{2}{*}{ Roll } & \multicolumn{2}{|c|}{ Total deviation } \\
\hline & & & & & & & Linear & Angular \\
\hline & $\mathrm{mm}$ & $\mathrm{mm}$ & $\mathrm{mm}$ & $\circ$ & $\circ$ & $\circ$ & $\mathrm{mm}$ & 。 \\
\hline 1 & 1.23 & 0.93 & 1.25 & 6.81 & 2.19 & 9.41 & 1.99 & 11.71 \\
\hline 2 & 0.53 & 1.02 & 0.57 & 1.43 & 1.71 & 4.41 & 1.28 & 4.92 \\
\hline 3 & 0.54 & 1.28 & 0.79 & 1.38 & 1.03 & 4.75 & 1.60 & 5.05 \\
\hline 4 & 1.89 & 1.80 & 0.94 & 2.93 & 1.88 & 5.35 & 2.78 & 6.35 \\
\hline 5 & 1.13 & 0.91 & 0.72 & 3.08 & 2.34 & 3.51 & 1.62 & 5.18 \\
\hline 6 & 1.92 & 2.17 & 1.49 & 7.29 & 4.88 & 10.74 & 3.26 & 13.61 \\
\hline 7 & 1.14 & 1.47 & 1.07 & 6.00 & 2.29 & 4.88 & 2.14 & 7.99 \\
\hline Total & 1.31 & 1.44 & 1.02 & 4.74 & 2.59 & 6.66 & 2.19 & 8.49 \\
\hline
\end{tabular}


a)

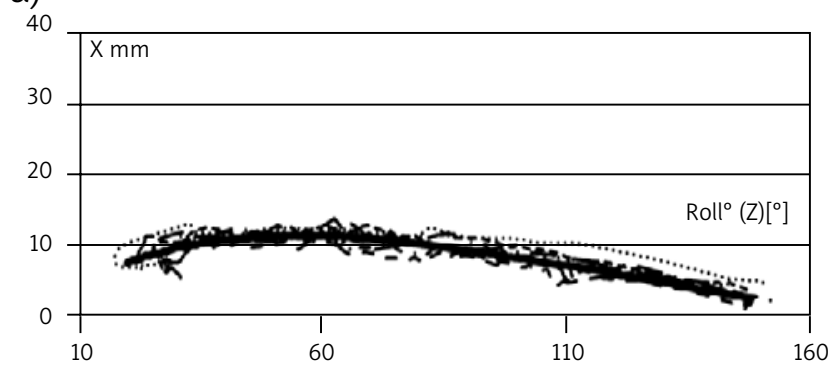

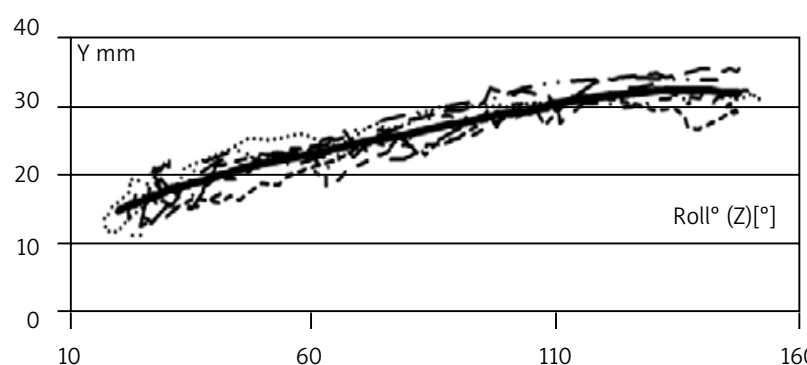

10

b)
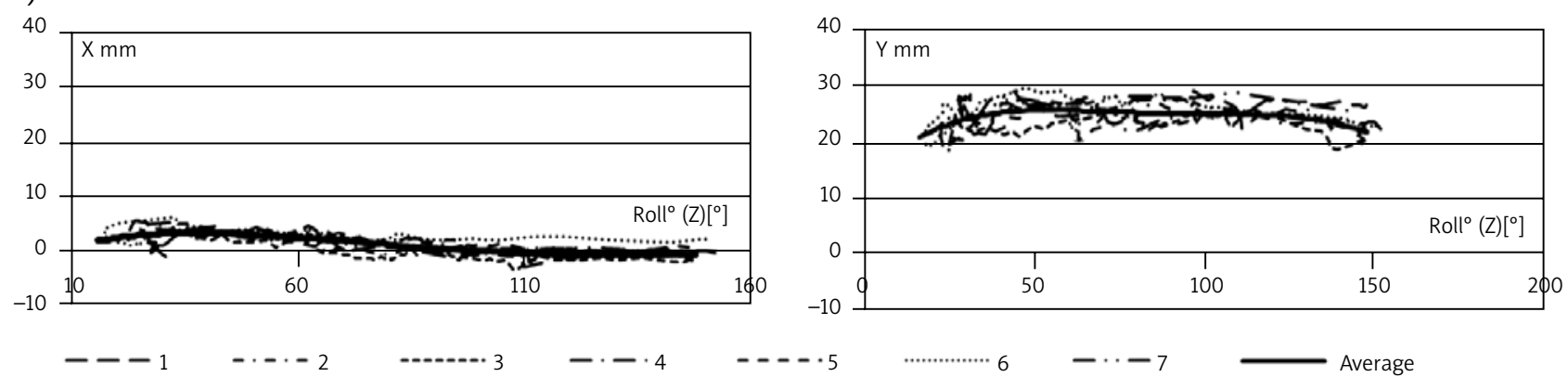

Fig. 5. The positions in axes $X$ and $Y$ in the Roll function for: $a$ ) the middle of the needle's curve, b) the point at which the needle is gripped by the vise

roll angle within the range of $40-90^{\circ}$ ), the instantaneous axis of needle rotation runs approximately $3 \mathrm{~mm}$ below the needle grip point (in the negative direction of axis $Y$ ). In accordance with the above, it can be concluded that the additional hypothesis is false, and the axis of the movement of piercing the needle into the tissue is situated closer to the point where the needle is gripped by the vise than to the point associated with the center of the needle's curve.

In order to verify that the registered suturing process was representative, 10 analogous experiments were performed. As problems with defining ball position occurred in 3 cases, the results of 7 experiments were taken into consideration. Subsequently, the average courses were compiled on one chart. For the data prepared in this man- ner, the average trajectory of the whole experiment was defined (7 suturing experiments, 7 suturing movements each - Fig. 6) along with the standard deviation for each average trajectory of a single experiment in relation to the average trajectory of the whole experiment, as well as overall mean standard deviation (Table II).

As can be observed in Figure 6 and Table II, the courses are similar in all 7 experiments, and the standard deviation remains within the range of $2 \mathrm{~mm}$. Therefore, it can be concluded that the movement associated with piercing the surgical needle into tissue is a repeatable movement. For this reason, it was decided to use this very movement in further research on the algorithms of providing support to the surgeon in the performance of stereotypical movements.

Tab. II. Standard deviations of the average courses of individual suturing experiments from the average trajectory of the whole experiment

\begin{tabular}{|c|c|c|c|c|c|c|c|c|}
\hline \multirow{3}{*}{ Process number } & \multirow{2}{*}{$\mathrm{x}$} & \multirow{2}{*}{ y } & \multirow{2}{*}{$\mathrm{z}$} & \multirow{2}{*}{ Yaw } & \multirow{2}{*}{ Pitch } & \multirow{2}{*}{ Roll } & \multicolumn{2}{|c|}{ Total deviation } \\
\hline & & & & & & & Linear & Angular \\
\hline & $\mathrm{mm}$ & $\mathrm{mm}$ & $\mathrm{mm}$ & $\circ$ & $\circ$ & $\circ$ & $\mathrm{mm}$ & $\circ$ \\
\hline 1 & 1.60 & 1.24 & 0.84 & 6.37 & 9.65 & 4.85 & 2.19 & 12.32 \\
\hline 2 & 0.76 & 1.20 & 0.35 & 5.51 & 1.49 & 4.51 & 1.46 & 7.23 \\
\hline 3 & 0.49 & 1.16 & 1.42 & 5.51 & 5.02 & 6.84 & 1.89 & 9.95 \\
\hline 4 & 0.50 & 0.49 & 1.20 & 1.97 & 2.70 & 2.91 & 1.39 & 4.40 \\
\hline 5 & 0.89 & 0.98 & 1.15 & 4.54 & 5.74 & 2.79 & 1.75 & 7.75 \\
\hline 6 & 0.50 & 0.49 & 1.20 & 1.97 & 2.70 & 2.91 & 1.39 & 4.40 \\
\hline 7 & 0.70 & 0.70 & 0.90 & 3.40 & 4.46 & 8.15 & 1.34 & 9.78 \\
\hline Total & 0.86 & 0.95 & 1.06 & 4.49 & 5.18 & 5.09 & 1.66 & 8.42 \\
\hline
\end{tabular}



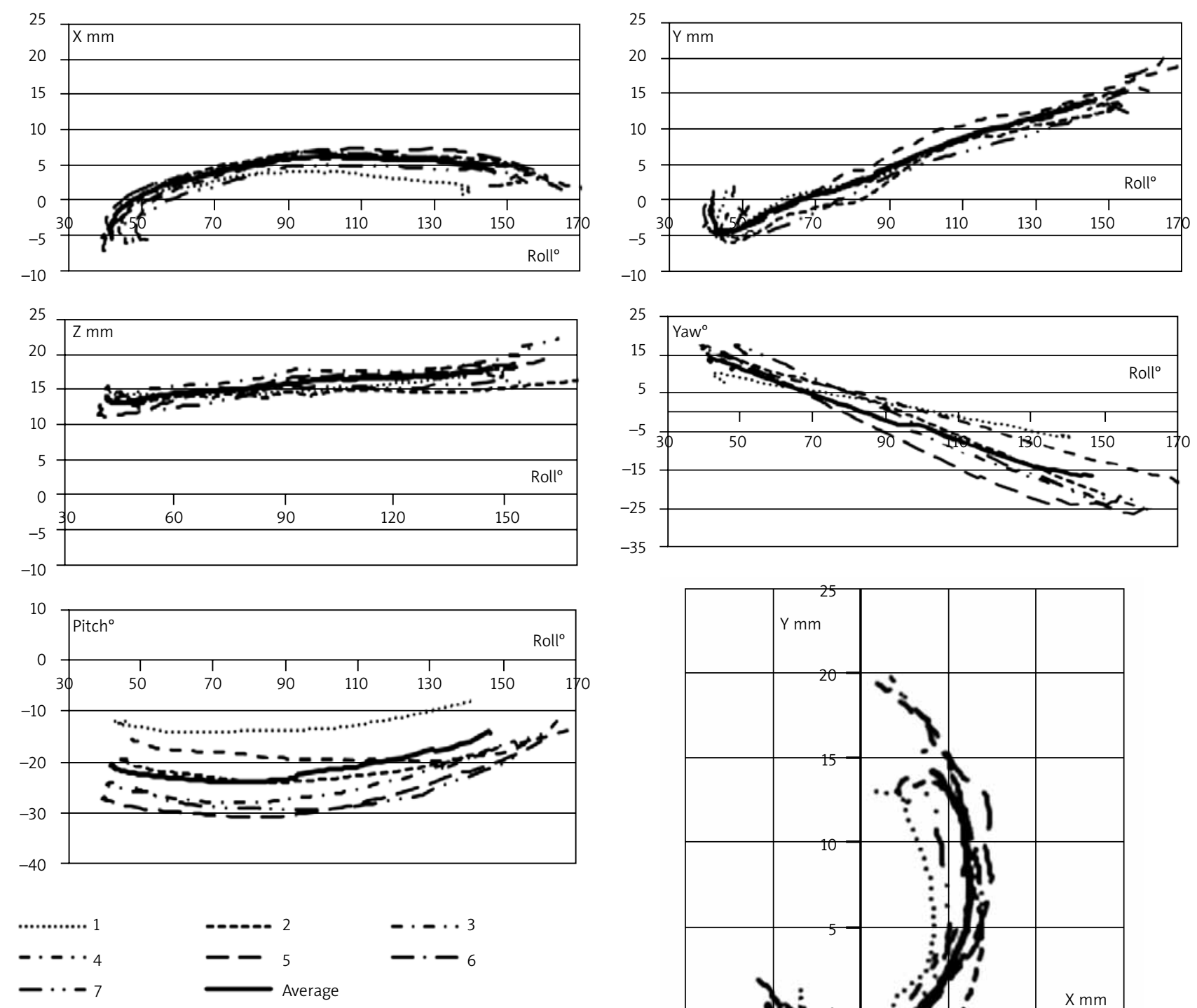

Fig. 6. Paths of the needle tip averaged from 7 suturing experiences

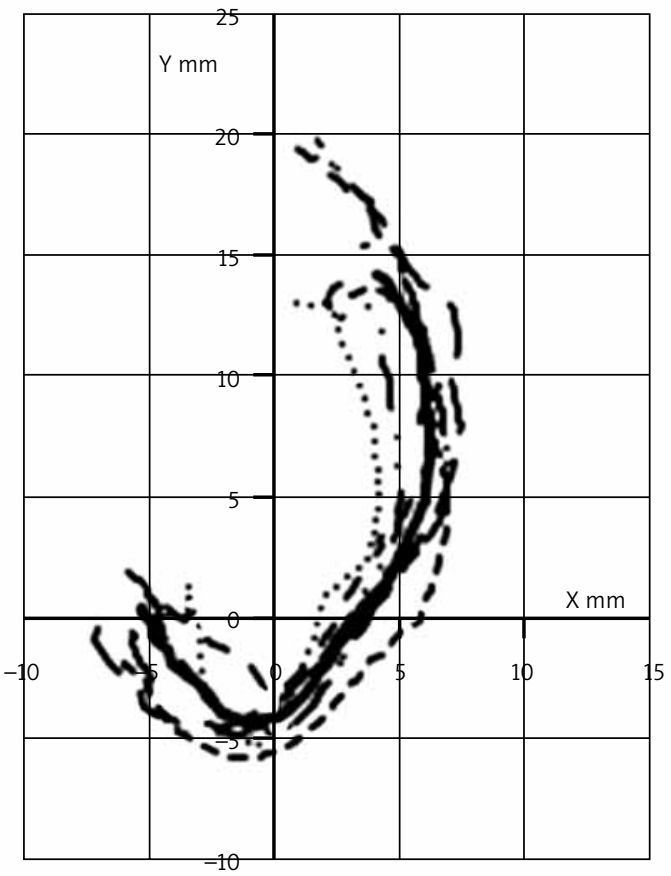

Based on the experiments, it can also be concluded that the axis of needle rotation is not parallel to axis $Z$ of the coordinate system designated by the surgeon, but the angle between them is relatively small (up to $15^{\circ}$ ). As the needle is linked with the tool, the recorded courses indicate that the tool's axis is slanted in relation to the wound.

In order to check suturing process repeatability for different surgeons, another surgeon's movements associated with tissue suturing were recorded. Next, a randomly selected trajectory of the first surgeon was compared with a randomly selected trajectory of the second surgeon, as presented in Figure 7. The figure shows three parameters of needle movement: positions $X$ and $Y$ of the needle tip and the needle's Roll rotation around axis $Z$ - the center of the needle's curve. Axis $Z$ is defined as the axis parallel

to the wound, while axis $X$ lies on the plane of the sutured tissue. Movement direction is reflected by the increasing values of coordinate $X$ and Roll angle. In comparison to previous courses, the zero position in the axis of the angle of roll rotation was different. The value of this angle is 0 if the tangent line to the needle at the needle tip is parallel to the sutured tissue.

As can be observed in Figure 7, both courses exhibit certain similarities.

The presented courses indicate that surgeon 1 performs the whole movement quite fluently. First, the surgeon pierces into the tissue with a movement tangent to the needle point; next, the surgeon guides the tip over an approximately circular trajectory with constant change of orientation; after puncturing through the tissue, the surgeon 


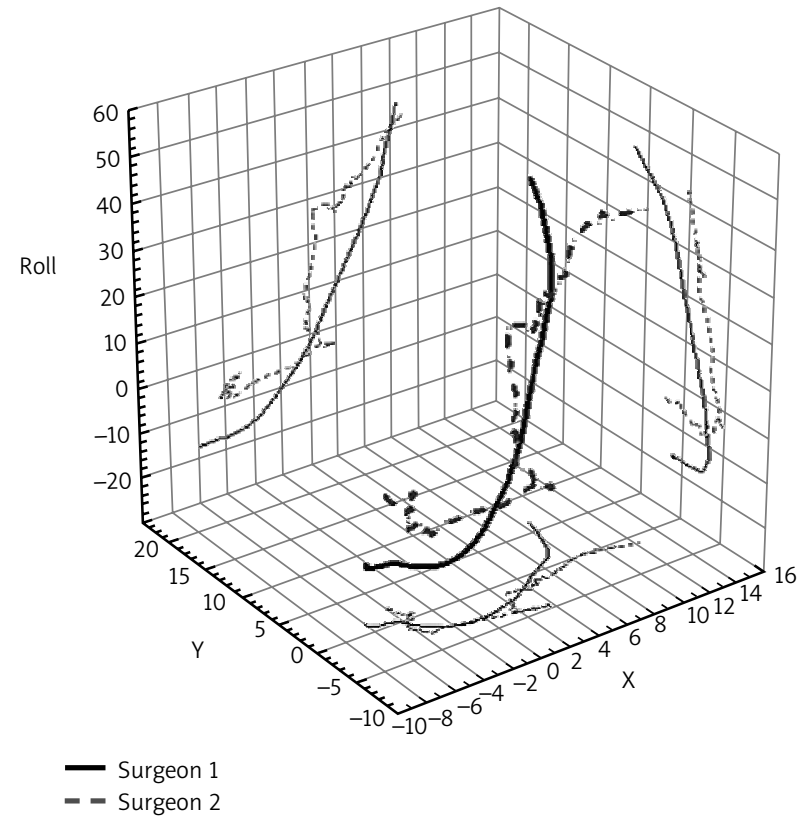

Fig. 7. A comparison of suturing courses performed by different surgeons

moves the needle relatively high above the wound. In the case of surgeon 2, clear stages of the needle's movement can be distinguished. During the first stage, he moves the needle down perpendicularly to the tissue (with constant values of coordinate $x$ and rotation angle), pushing it approximately $3 \mathrm{~mm}$ into the tissue (but without piercing it at this stage, as demonstrated by film analysis). During the second stage, the movement is parallel to the tissue surface without changes in orientation. The third stage leads to guiding the needle tip above the sutured tissue and is primarily performed by rotating the needle - increased roll angle and concurrent rise in the y coordinate, as well as slight (probably unintended) displacements in direction $\mathrm{x}$. The last stage, aimed at piercing the needle out of the tissue so that it can be gripped again, is performed primarily by moving the needle in direction y (across the incision) with minute changes of the needle rotation angle. Unfortunately, as multiple experiments could not have been conducted for the second surgeon, and a different method of recording was used, this part of the experiment does not provide a basis for statistical analysis and the defining of numerical repeatability parameters for different surgeons. The experiment does, however, illustrate the fact (obvious for some, surprising for others) that the tool paths recorded during the same suturing process vary for different surgeons, even though they contain certain similar fragments. This variety may result from the surgeon's experience or habits. Several questions should be posed at this point: Are both movements equally good? Can one optimal movement trajectory be defined under identical external conditions? Would it be worthwhile to introduce training concerning moving along such an optimal trajectory into the surgical education process?
At the current stage of research, these questions cannot yet be answered, but they do indicate possible directions for further study.

\section{Conclusions}

The present article defined the concept of surgical movement repeatability as well as a methodology for classifying movements as repeatable or non-repeatable. However, the proposed arbitrary division requires studies that would enable the confirmation of its validity. A method was developed for measuring tool trajectories using stereo vision, and a methodology of defining characteristic points of the surgical site was designed. Using these procedures, the hypothesis that the suturing movement of a given surgeon is a repeatable movement was verified. For the studied movement and the selected tissue, needle, and incision length, linear repeatability was established at $1.66 \mathrm{~mm}$, and angular repeatability at $8.4^{\circ}$.

Random comparison studies were also performed for different surgeons; they indicated that, under similar conditions, the manner in which each surgeon guides the needle is repeatable but different. The repeatability of surgical movements cannot, therefore, be postulated for the whole surgeon population. One of the possible directions of further study is to determine the optimal trajectory conditions in relation to patient health and ascertain which trajectories should be considered while planning a trajectory for a surgical robot.

The studies described in the present article enable only a partial answer to the question posed in the title: there are repeatable surgeon movements, and the selected suturing motion is one example of such movement. This conclusion opens up a new direction in surgical telemanipulator studies. Until now, remote manipulators, such as Zeus, da Vinci, or Rob/n Heart, would operate only by copying the movements of the surgeon and eliminating hand tremors. Establishing the repeatability of selected movements - referred to as movement stereotypes for the purpose of this and subsequent articles - confirms the possibility of introducing partial automation to their performance. Furthermore, the validity of the search for methods of providing support to surgeons is corroborated by the analysis of the tool paths resulting from the performance of the same movements by two different surgeons. The said analysis has indicated that each surgeon guides the tool over a slightly different path. It can be surmised that the quality of the introduced sutures can vary in the case of different paths. Continuing this line of reasoning, it can be presumed that there is at least one path for which the quality of the suture is the best. Such a path can be referred to as an optimal path. The desired method of providing support to surgeons in guiding the tool with a surgical telemanipulator during stereotypical movements should result in the performance of such optimal paths. However, considering the fact that each surgical procedure is slightly different and depends on individual anatomical characteristics of patients and their condition, further study will concentrate on finding 
a control algorithm that will both aid the surgeons and allow them to maintain complete control over the conducted procedure.

Apart from trajectory control, selecting the reference points on the basis of which the reference coordinate system is designated is a key element of performing the suturing procedure correctly. The course of the path (the coordinates of points lying on the path) depends on the position of the coordinate system in relation to which the measurement is taken. Improper selection of the reference points may result in errors in defining both repeatability and the average path. It is also crucial to define repeatability conditions and, at further stages, the conditions of generating the trajectory of the needle. This is related to the selection of the movements that are to be repeatable throughout the whole suturing procedure (several sutures) as well as the reference points in relation to which the movements are to be defined. Are the 6 basic reference points sufficient for the whole procedure? Or should the surgeon be allowed to introduce additional reference points in order to facilitate the procedure? The algorithms planned for development will assist surgeons in their work by automating stereotypical movements while, concurrently, allowing the operator to modify any procedure element if their experience and intuition suggest the possibility of guiding the tool over a trajectory that is more optimal than the one generated by the control system.

The conducted experiments described in the article permit certain conclusions to be drawn concerning the path of the needle during suturing. The surgeon guides the needle in such a way as to ensure that the path of the needle tip inside the tissue is approximately circular. It turns out, however, that the center of this circle (or the instantaneous axis of needle rotation) is relatively distant from the axis of the curve of the needle itself, which generates tensions within the operated tissue during suturing.

Further studies are planned to check the repeatability of suturing motion performed using the surgical manipulator Rob/n Heart and to compare them with the repeatability values obtained during experiments presented in this article. Subsequently, studies using newly designed algorithms will be conducted, and both movement repeatability and suture quality will be compared.

\section{Acknowledgments}

This scientific study was financed from research funds for the years 2011-2014 as research project no. NCN 2011/01/B/ST7/0401.

\section{References}

1. Thyavihally Y, Pednekar A, Pokharkar H. Da Vinci Robot Assisted Video Endoscopic Inguinal Lymphadenctomy (R-Veil): Initial Experience. J Urol 2013; 189: E349-E349.

2. Han-Xin Z, Yue-Hua G, Xiao-Fang Y, Shi-Yun B, Jia-Lin L, Yue Z, Yong-Gong R. Zeus robot-assisted laparoscopic cholecystectomy in comparison with conventional laparoscopic cholecystectomy. HBPD INT 2006; 5: 115-118.

3. NawratZ, Podsedkowski L, Mianowski K, WroblewskiP, Kostka P, BaczynskiM, Maklota Z, Granosik G, Jezierski E, Wroblewska A, Religa Z. Robin Heart in 2002 - Actual state of polish cardio-robot. RoMoCo'02; Procideengs of the Third International Workshop on Robot Motion and Control 2002; 33-38.

4. Nawrat Z, Podsedkowski L, Mianowski K, Wroblewski P, Kostka P, Pruski R, Malota Z, Religa Z. Robln Heart 2003 - Present state of the Polish telemanipulator project for cardiac surgery assistance. Int J Artif Organs 2003; 26: $1115-1119$

5. Podsedkowski L, Zak P. Tests on Cardiosurgical Robot Robln Heart 3. Robot Motion and Control 2009, Lecture Notes in Control and Information Sciences 2009; 396: 433-442.

6. Nawrat Z, Kostka P, Dybka W, Rohr K, Sadowski W, Podsedkowski L, Wroblewski P. The Advances of Robin Heart Uni System - From Virtual to Real Model, From Laboratory to First Vivo Experiments. Int J Artif Organs 2008; 32: 433-433.

7. Nawrat Z. The Robin Heart story. Medical Robotics Reports 2012; 1: 19-21.

8. Kobierska A. Force sensor for laparoscopic tool of Robln Heart robot. Diffusion and Defect Data Pt.B: Solid State Phenomena 2013; 199: 309-314.

9. Fracczak L. Mathematical model of the servo drive with friction wheels. Simulations and real object examination results. Diffusion and Defect Data Pt.B: Solid State Phenomena 2013; 198: 15-20.

10. Camarillo DB, Krummel TM, Salisbury JK Jr. Robotic technology in surgery: past, present, and future. Am J Surg 2004; 188: 2-15.

11. Acrobot Precision Surgical System [Online]. The Acrobot Company Limited. http://www.acrobot.co.uk

12. Geer D. Pervasive Medical Devices: Less Invasive, More Productive. IEEE Pervasive Computing 2006; 5: 85-87.

13. Polska Norma, PN-EN ISO 9283/2003 Roboty Przemysłowe - Metody badania charakterystyk funkcjonalnych.

14. BrainLAB [Online]. http://www.brainlab.com. 